\title{
Effects of Brain Gymnastics on Decreased Stress Levels in College Students
}

\author{
Sri Sartini ${ }^{1}$, Amirullah ${ }^{2}$, Aszrul $A B^{3 *}$ \\ S1 Nursing Study Program, Stikes Panrita Husada Bulukumba, Indonesia ${ }^{1}$ \\ Departemen Surgical Medical Nursing ,Stikes Panrita Husada Bulukumba, Indonesia ${ }^{2}$ \\ Departemen Community And Family Nursing, Stikes Panrita Husada Bulukumba, \\ Indonesia ${ }^{3}$
}

*Corresponding Autor : aszrulrul@gmail.com

\begin{abstract}
The background of this study is non-pharmacological management to reduce stress one of which is brain gymnastics. Brain gymnastic movements can activate neocortex and sympathetic nerves to reduce the increased production of adrenaline hormone in the body that can relieve psychological tension as well as physical tension. The purpose of this study is to find out the effect of brain gymnastics on the decrease in stress levels in students of the final level of the DIII Health Analyst Stikes Panrita Husada Bulukumba in 2019. The method used is this research using a pre-experiment research design with the one group pre-post test design method. Sampling by means of Nonprobability sampling: Consecutive sampling with a total of 28 respondents. Measurement of stress levels using a watershed questionnaire (Depression Anxienty Stress Scale) with statistical tests used is a paired t test. The results of this study showed that there was an effect of brain gymnastics exercise on the decrease in stress levels in students of the final level of the DIII Health Analyst Stikes Panrita Husada Bulukumba with a mean Pretest score of 22.61 while the mean Postest 12.75 so that the average value of changes in pretest and posttest stress levels with a mean value of 9,857 with a std.deviation of 3,354 . In conclusion, there is a meaningful influence on brain gymnastics training on the decrease in stress levels in students of the final level of the DIII Health Analyst Stikes Panrita Husada Bulukumba 2019.
\end{abstract}

Keywords: Brain Gymnastics Exercises, Stress Levels

\section{INTRODUCTION}

Stress is a physical and psychic reaction to any demands that causes tension and disrupts the stability of daily life.(Priyoto, 2014). Normal stress is experienced by each individual and becomes an integral part of life. Stress makes a person who experiences it think and try hard in solving a problem or challenge in life as a form of adaptation response to stay afloat.(Rahayu, 2017). Academic stress is defined as a condition or state of individuals who experience stress as a result of students' perceptions and assessments of academic stressors, which are related to science and higher education.(Rahayu, 2017).

Vol.5, No.2 Agustus 2021

https://doi.org/10.37362/jch.v5i2.594 


\section{COMPRERIENSTE HIALHF CARD}

According to the World Health Organization (2017) in general, mental disorders that occur are mental stress disorders, anxiety and depressive disorders. An estimated $4.4 \%$ of the global population suffers from emotional stress disorders and 3.6\% of anxiety disorders. The number of stress sufferers increased by more than $18 \%$ between 2005 and 2015(WHO 2017).

Based on data from Regional Health Research (2013-2018) the prevalence of emotional mental disorders in the Indonesian population increased from 2013 by $6.0 \%$ to 9.8\%, while in the province of South Sulawesi which experienced emotional mental disorders (Anxiety, Stress and depression) continued to increase from $9.2 \%$ to $12.5 \%$ (Kementrian Kesehatan, 2018). Scalavitz (2011) states that the prevalence of students in the world experiencing stress ranges from 38-71\%, while in Asia 39.6 - 61.3\% (Koochaki et al, 2009). In Indonesia, 36.7 - 71.6\% of students experience stress.(Fetri, 2017).

Based on preliminary studies or preliminary data conducted by researchers on 60 students of DIII health analysts last semester at the beginning of december 2018 the results showed that 10 students experienced mild stress, 12 people who experienced moderate stress and 6 students who experienced severe stress using watershed scale (Depression Anxiety Stress Scale). So the researchers concluded that there is still a high incidence of stress in students of Diii Health Analyst Stikes Panrita Husada Bulukumba this is caused because prosi DIII Health analyst Stikes Panrita Husada Bulukumba is the first generation. The purpose of this study was to analyze the effect of brain gymnastics on the decrease in stress levels in students of the final level of the DIII Health Analyst Stikes Panrita Husada Bulukumba.

\section{MATERIAL AND METHODS}

The type of research used in this study is a pre-experimental research design with the one group pre-post test design method which is to reveal a cause-and-effect relationship by involving one group of subjects, where the group of subjects is observed before the intervention, then observed again after being given an intervention to see the change or influence of the given intervention.(Nursalam, 2017). The population in this study was all students of the final level of the DIII Health Analyst Panrita Husada Bulukumba study 
program which amounted to 60 people consisting of two classes between class A and class B.

The sampling technique used is Nonprobability sampling: Consecutive sampling which is the selection of samples by assigning subjects who meet the research criteria included in the study up to a certain period of time, so that the number of samples needed is met (Nursalam, 2017). So that the sample in this study is as many as 28 students of the final level of the DIII Health Analyst Panrita Husada Bulukumba study program. Data analyzed based on the measurement scale of stress variables is a questionnaire in the form of the standard Depression anxiety Stress scale (WATERSH) and the purpose of the study using computerized program software.data is analyzed by: (1) Univariate Analysis, which is an analysis used to see the distribution of respondent characteristics (Proportions). (2) Bivariate analysis, bivariate test is conducted to look for differences or influences between independent variables and dependent variables with the test used is the test paired with the confidence interval taken is $95 \%$ and the meaningful limit received when $\mathrm{p}<0.05$.

\section{RESULTS}

Table 1. Frequency Distribution Based on Respondent Characteristics

\begin{tabular}{ccc}
\hline Characteristics of Respondent & Frequency (F) & Percent (\%) \\
\hline Age (Year) & 1 & 3.6 \\
19 & 7 & 25.0 \\
20 & 14 & 50.0 \\
21 & 4 & 14.3 \\
22 & 1 & 3.6 \\
24 & 1 & 3.6 \\
27 & & \\
Gender & 4 & 14,3 \\
Male & 24 & 85,7 \\
Female & $\mathbf{2 8}$ & $\mathbf{1 0 0 .}$
\end{tabular}

Based on table 1 shows that the age of respondents in this study is the highest is respondents aged 21 years as many as 14 respondents (50\%), while the lowest is those 
aged 19 years, 24, and 27 years respectively 1 respondent (3.6\%). The sex in the study was mostly female, with 24 respondents (85.7\%), and in male respondents there were only 4 respondents (14.3\%).

Table 2. Frequency Distribution Based on Respondents' Stress Level Characteristics Before Intervention

\begin{tabular}{ccc}
\hline Stress Levels & Frequency (F) & Percent (\%) \\
\hline Normal & - & - \\
Mild Stress & 7 & 25,0 \\
Moderate Stress & 14 & 50,0 \\
Severe Stress & 6 & 21,4 \\
Stress is very heavy & 1 & 3,6 \\
\hline Amount & $\mathbf{2 8}$ & $\mathbf{1 0 0}$ \\
\hline
\end{tabular}

Based on table 2 showed that the frequency distribution of stress levels before being given brain gymnastics interventions in this study was mostly in the category of moderate stress, namely as many as 14 respondents (50\%), while those who experienced the lowest stress levels there was 1 respondent (3.6\%) who experienced very severe stress.

Table 3. Frequency Distribution Based on Characteristics of Respondents' Stress Levels After Intervention

\begin{tabular}{ccc}
\hline Stress Levels & Frequency (F) & Percent (\%) \\
\hline Normal & 16 & 57,1 \\
Mild Stress & 9 & 32,1 \\
Moderate Stress & 2 & 7,1 \\
Severe Stress & 1 & 3,6 \\
Stress is very heavy & - & - \\
\hline Amount & 28 & 100
\end{tabular}

Based on table 3 showed that the frequency distribution of stress levels after being given brain gymnastics interventions in this study decreased, namely at the stress level of most respondents who did not experience stress (Normal) as many as 16 respondents (57.1), and respondents who experienced mild stress as many as 9 respondents (32.1\%) and respondents who experienced moderate stress levels decreased to 2 respondents (7.1), 
And at the level of stress is very stressed there is only 1 respondent (3.6\%), and no respondents who experience very severe levels of stress.

Table 4. Distribution Based on The Average Value of Respondents' Stress Levels Before And After Intervention

\begin{tabular}{lccc}
\hline & Mean & Std.Deviation & N \\
\hline Pre & 22.61 & 5.252 & 28 \\
Post & 12.75 & 5.448 & 28 \\
\hline
\end{tabular}

Based on table 4 it can be explained that before being given brain gymnastics exercise on the overall number of respondents as many as 28 respondents, the average stress experienced by respondents with a value of 22.61 while after being given brain gymnastics exercise the average stress experienced by respondents, decreased by a mean value of 12.75 .

Table 5. Analysis of Stress Levels Before And After Being Given Brain Gymnastics Exercise Intervention

\begin{tabular}{lllcc}
\hline Mean & Std.Deviation & Correlation & N & $\begin{array}{c}\text { P-Value } \\
\text { Sig.(2 tailed) }\end{array}$ \\
\hline Pretest & & &
\end{tabular}

\begin{tabular}{llllll}
\hline Pretest & 9.857 & 3.352 & 0.804 & 28 & 0.000 \\
Postest & & & & &
\end{tabular}

Based on table 5, the results found that the average change in the level of stress in students at the end level between pretest brain gymnastics exercise and posttest brain gymnastics exercise is with a mean of 9,857 which means that there is a meaningful average change in the level of stress pretest and posttest brain gymnastics exercise, while the distribution of data in the sample is with a standard deviation of 3,352 out of the total number of respondents as many as 28 respondents with the results of the analysis showed that the significant mean between pre test and post test in the provision of brain gymnastics exercise is known asymp.sig. (2-tailed) is worth 0.000. Because the value of 0.000 is smaller than the $<0.05$, it can be interpreted that "Ha is accepted" which means there is an Effect of Brain Gymnastics On The Decrease in Stress Levels in Students of The Final Level of Study Program DIII Health Analyst Stikes Panrita Husada Bulukumba in 2019.

\section{DISCUSSION}

Based on table 1, it is known that the overall age of respondents of students has entered the category of early adulthood, where most of the respondents are 21 years old. So 
researchers believe that the age of final-level students in this research is at the stage of late adolescence development towards early adulthood. Based on table 2, it is known that the respondents as a whole are mostly female. This is because the number of female respondents is more than the number of male respondents with the number of women as many as 24 respondents (85.7) and men as many as 4 people (14.3). So researchers assume that the female sex has a higher interest in the profession as a health analyst or health worker than men, so the type of female commoner dominates in this study and the nature of some women who have a level of sensitivity or sensitivity to something so this is what causes them very easily and range experiencing stress.

Table 3 shows that most students experience moderate stress as many as 14 respondents (50\%). This is in line with previous research on final-level students by (Sitti Nurfaaiqah, 2015) Which shows that before being given brain gymnastics the majority of students who experienced moderate stress were more as many as 9 respondents (45\%) than the overall 20 respondents. So researchers can assume that at the level of moderate stress is most experienced by final-level students, because in these conditions disputes or problems faced by students lead to self-adjustment to local conditions, where the individual's response in realizing that there are systematic changes in life that must be faced and this lasts longer.

Based on table 4 there was a decrease in the level of stress both from very severe stress to severe stress, students who experienced severe stress there was only 1 respondent (3.6\%), while moderate stress there were 2 respondents (7.1\%) and those who experienced mild stress there were 9 respondents (32.1\%) and significant changes were seen as many as 16 respondents (57.1\%) who had not experienced stress (Normal). This is in line with the research conducted by(Sitti Nurfaaiqah, 2015) It was found that each category of stress in Final-Level Students decreased, while there were students who did not experience stress (Normal) as many as 4 respondents (20.0\%) so researchers assumed that the decrease in stress levels in students at the end of the study program diii health analysts were caused by brain gymnastics exercise interventions given. Brain gymnastic movements are fun and also very easy to do so that it can revive morale and concentration, and one of the benefits of brain gymnastics is that it can reduce the symptoms of stress. 
The average change in stress levels in final-level students between pretest brain gymnastics exercise and posttest brain gymnastics exercise is with a mean of 9,857 which means that there is a meaningful average change in the level of stress pretest and posttest brain gymnastics exercise, With the results of the study showed that the significant mean between pre test and post test in doing brain gymnastics exercises is known asymp.sig. (2tailed) is worth 0.000 . Because the value of 0.000 is less than the $<0.05$ it can be concluded that "Ha accepted" and "Ho rejected" which means there is a meaningful difference between the level of stress before and after being given a brain gymnastics exercise intervention.

This is according to the researchers because respondents perform brain gymnastic movements that are useful to overcome physical and psychological tension, namely emotional disorders such as anxiety and stress that occur due to various stressors faced by students, so that the stress experienced by students experience a significant decrease.

Researchers also believe that the decrease in stress that occurs in respondents is caused by because respondents are given brain exercise interventions. These brain gymnastic movements are one of various types of exercise, where when we exercise not only the physical fitness we get but our mental health also increases.

According to (Purwanto and Widyaswati, 2009) Brain gymnastic movements are made to stimulate (lateralis dimension) for the left and right hemispheres of the brain, lighten (Focusing Dimension) for the brain and brain stem (brainstem) and the front part of the brain (frontal lobes), and relax (concentration dimension) for the limbic system (midbrain) and cerecral cortex. Brain gymnastic movements can activate neocortex and parasympathetic nerves to reduce the increase in adrenaline hormone in the body that can relieve psychological tension and physical tension, so that the soul and body can become more relaxed. This is also in line with the research conducted by (Nurdin, 2015) with a significant level of $(p=0.025)<0.05$ which states that there is an effect of brain gymnastics exercises on the decrease in stress levels.

\section{CONCLUSIONS AND SUGGESTIONS}

Based on the results of the above research, it was concluded that there is a meaningful difference between pre test and post test in the provision of brain gymnastics exercises known asymp.sig. (2-tailed) is worth 0.000 less than $<0.05$ so it can be concluded that "Ha 
accepted" means there is an Effect of Brain Gymnastics On Decreased Stress Levels with an average change in the mean value of 9,857 with a standard deviation of 3,352 in Final-Level Students of The Study Program DIII Health Analyst Stikes Panrita Husada Bulukumba in 2019. The results of this study hopefully can increase the insight of students at STIKES Panrita Husada Bulukumba and health workers to be able to use nonfamakology techniques to reduce patient stress levels.

\section{REFERENCE}

Amalia Erit Rina Fadillah, 2013. Stres Dan Motivasi Pada Mahasiswa Psikologi Universitas Mulawarman Yang Sedang Menyusun Skripsi. E-J. Psikol. 1.

Ayinosa, 2010. Brain Gym (Senam Otak). Kesehat. Ment.

Dadang Hawari, 2016. Manajemen Stres Cemas Dan Depresi, Edisi Ii. Ed. Fakultas Kedokteran Universitas Indonesi, Jakarta.

Dahlan, 2014. Statistik Untuk Kedokteran Dan Kesehatan. Salemba Medika, Jakarta.

Dahlan, M. Sopiyudin, 2016. Langkah-Langkah Membuat Proposal Penelitian Bidang Kedokteran Dan Kesehatan, 2nd Ed, 3. Sagung Seto, Jakarta.

Fetri, S.L., 2017. Hubungan Tipe Kepribadian Dengan Tingkat Stres Pada Mahasiswa Baru Fakultas Kedokteran Universitas Andalas Tahun 2016.

Fitria, D., 2010. Pengaruh Senam Otak (Brain Gym) Terhadap Tingkat Stres Pada Remaja Kelas Xii Ipa 1 Dan Xii Ipa 6 Di Sma Negeri 7 Padang Tahun 2010. Penelit. Fak. Keperawatan.

Heiman Dan Kariv, 2015. Task-Oriented Versus Emotion-Orieted Coping Strategies: The Case Of College Of Students. Collenge Stud. Jounal 1, 72-89.

Hidayat, 2010. Pengantar Konsep Dasar Keperawatan, 2nd Ed. Salemba Medika, Jakarta.

Hurbock, E, B., 2012. Development Psychology A Lifespan Approch. Mc Graw-Hill.

Kementrian Kesehatan, R., 2018. Riset Kesehatan Dasar (Riskesdas) 2018. Jkt. Badan Penelit. Dan Pengemb. Kesehat.

Lovibond, S.H \& Lovibond, P.F, 1995. Manual For The Depression Anxiety Stress Scale. Psychol. Found. 2.

Nurdin, N., 2015. Pengaruh Senam Otak Terhadap Stres Pada Santri Madrasah Mu'alimin Yogyakarta. 
Nursalam, 2017. Metodelogi Penelitian Ilmu Keperawatan, 4th Ed. Salemba Medika, Jakarta.

Priyoto, 2014. Konsep Manajemen Stress. Nuha Medika, Yogyakarta.

Purwanto, S., Widyaswati, R., 2009. Manfaat Senam Otak (Brain Gym) Dalam Mengatasi Kecemasan Dan Stres Pada Anak Sekolah.

Rahayu, K.I.N., 2017. Brain Gym Terhadap Tingkat Stres Pada Mahasiswa Program Studi Ilmu Keperawatan Fakultas Ilmu Kesehatan Universitas Kadiri. Dunia Keperawatan 5, 26-36.

Setiawan, R.A., Safitri, W., Setiyajati, A., 2014. Pengaruh Senam Otak Dengan Fungsi Kognitif Lansia Demensia Di Panti Wredha Darma Bakti Kasih Surakarta.

Setyoado, Kusharityadi, 2011. Terapo Modalitas Keperawatan Pada Klien Psikogeriatrik, 1st Ed. Salemba Medika, Jakarta.

Siswanto, 2012. Mekanisme Koping Stres, 1st Ed, 1. Sagung Seto, Yogyakarta.

Sitti Nurfaaiqah, 2015. Pengaruh Latihan Senam Otak Terhadap Penurunan Stres Pada Mahasiswa Tingkat Akhir S1 Keperawatan Program Reguler Yang Sedang Menyusun Skripsi Stikes Muhammadiyah Samarinda.

Sugiyono, 2017. Metode Penelitian Kuantitatif, Kualitatif, Dan R\&D, 26th Ed. Alfabeta, Bandung.

Sukadiyanto, 2014. Stres Dancara Penanggulangannya.

Susilawati, T.A.P., Jeremia Maruhawa, Yeni Sinturi, Simijatun, 2012. Konsep Dasar Keperawatan Kesehatan Jiwa, Monica Ester. Ed. Egc, Jakarta.

Suyanto, S., 2014. Metodelogi Penelitian Epidemiologi Bidang Kedokteran Dan Kesehatan. Bursa Ilmu, Yogyakarta.

Suyanto, S.Kp.,M.Kes, 2011. Metodelogi Dan Aplikasi Penelitian Keperawatan, 1st Ed. Nuha Medika, Jakarta.

Wahyuni, A.S., Damaiyanti, S., Sari, V.P.M., Ridwan, R., Susanti, A., 2015. Pelaksanaan Senam Brain Gym Terhadap Tingkat Kecerdasan Emosional Anak Usia Prasekolah (4-5 Tahun) Di Paud Ibnu Sina Bukittinggi. 'Afiyah 2.

World Health Organization, 2017. Who. International.

Yuarita, 2012. Senam Otak (Brin Gym). Salemba Medika, Jakarta.

Zulaini, Z., 2017. Manfaat Senam Otak. J. Ilmu Keolahragaan 15, 62-70. 


\section{OMPREHENSTVE HEALH CARE}

Zuriska Kumalasari, 2016. Pengaruh Pelatihan Senam Otak Terhadap Anak Tunagrahita Ringan Di Sdlb C Pertiwi Ponorogo. 